\title{
Нарушения опорно-рессорной функции стопы юных баскетболистов и ее профилактика в тренировочном процессе
}

\author{
УДК 796.323.4-0538:611.986.068(043.3) \\ К. Н. Сергиенко, С. В. Строганов, О. А. Шинкарук, \\ Н. Г. Бышевец, Н. Н. Гончарова, А. В. Жирнов
}

Национальный университет физического воспитания и спорта Украины, Киев, Украина

\begin{abstract}
Резюме. Мета. Розробити технологію профілактики нефіксованих порушень стопи й перевірити їі ефективність. Методи. Аналіз і узагальнення науково-методичної літератури, даних мережі Інтернет, документальних матеріалів; антропометрія з використанням стопометра; біомеханічний відеокомп'ютерний аналіз опорно-ресорних властивостей стопи за програмою «BigFoot»; тензодинамометрія із застосуванням тензоплатформи «Kistler»; відеокомп'ютерний аналіз рухів системи «Qualisys»; методи математичної статистики. Результати. Виявлено негативний вплив порушень стопи на опорну реакцію юних баскетболістів при виконанні основних технічних прийомів: при виконанні стрибка вгору з місця відштовхуванням двома ногами максимальна сила реакції опори при відштовхуванні коливається в межах 1243-1476 Н, при приземленні - 2437-2976 Н; зареєстрована висота стрибка становила від 0,28 до 0,41 м. У початківців з порушеннями опорно-ресорних властивостей стопи зазначені показники становили 1315,42 і 2806,67 Н відповідно при висоті стрибка 0,34 м. У юних баскетболістів з нормальною стопою вище показники висоти стрибка вгору-вперед з розбігу відштовхуванням однією ногою $(p<0,05)$, довжини стрибка $(p<0,05)$, довжини траєкторії переміщення ОЦМ за стрибок $(p<0,05)$ порівняно зі спортсменами, які мають порушення опорноресорної функції стопи. Порушення стану стопи негативно позначається на виконанні спортсменами зупинок стрибком і кроком. Розроблена технологія профілактики порушень опорно-ресорних властивостей стопи юних баскетболістів дозволила ввести комплекс фізичних вправ на нестійкій опорі, що передбачають використання балансуючої платформи «bosu», на пружній і м'якій поверxнях, рухливі ігри, які сприяють зміцненню м'язово-зв'язкового апарату стопи юних баскетболістів. Висновок. Перспективним напрямом вдосконалення тренувального процесу юних баскетболістів $€$ спеціальні технології профілактики порушень опорно-ресорної функції стопи, яка була нами розроблена на основі встановлених особливостей взаємодій між стопою і опорою при грі в баскетбол. Ключові слова: баскетбол, травматизм, початковий етап, підготовка, стопа, властивості, взаємодія, реакція, опора, порушення, технологія.
\end{abstract}

Disorders of the support-spring function of the foot of young basketball players and its prevention in the training process

K. N. Sergiyenko, S. V. Stroganov, O. A. Shynkaruk, N. G. Byshevets, N. N. Goncharova, A. V. Zhirnov

National University of Physical Education and Sport of Ukraine, Kyiv, Ukraine

Abstract. Objective. To develop a technology for the prevention of unfixed foot disorders and verify its effectiveness. Methods: analysis and generalization of scientific and methodological literature, Internet data, documentary materials; anthropometry using a stopometer; biomechanical video-computer analysis of support-spring properties of the foot according to the "BigFoot" program; tensodynamometry with the use of the "Kistler" platform; video computer analysis of "Qualisys" system movements; methods of mathematical statistics. Results. The negative effect of foot disorders on the support reaction of young basketball players was revealed during performance of the main technical skills: during performance of counter movement jump off both feet, the maximum reaction force of the support during takeoff ranges from 1243-1476 N, whereas during landing - 2437-2976 N; the recorded jump height ranged 
from 0.28 to $0.41 \mathrm{~m}$. In novice athletes with disorders of the support-spring properties of the foot, the above indices were 1315.42 and $2806.67 \mathrm{~N}$, respectively, with a jump height of $0.34 \mathrm{~m}$. In young basketball players with a normal foot higher indices of the height of upward-forward running jump with one leg take-off ( $p<0.05)$, its length ( $p<0.05)$, the length of the trajectory of the GCM per jump $(p<0.05)$ as compared to athletes with impaired support-spring function of the foot were observed. Disorders of the foot condition adversely affect the athletes performing stops by jump and step. The developed technology for the prevention of disorders of the support-spring properties of the foot of young basketball players made it possible to introduce a set of physical exercises on an unstable support, involving the use of the "bosu" balancing platform on elastic and soft surfaces, and outdoor games that strengthen the muscular-ligamentous apparatus of the foot of young basketball players. Conclusion. A promising direction for improving the training process of young basketball players is special technologies for the prevention of disorders of the support-spring function of the foot, which we have developed on the basis of the established features of the interactions between the foot and support when playing basketball. Keywords: basketball, injuries, prevention, initial stage, preparation, foot, properties, interaction, reaction, support, technology.

Постановка проблемы. Высокий уровень тренировочных нагрузок в современном спорте и резкое расширение соревновательной практики в последние годы обострили проблему спортивного травматизма $[8,16,23]$. Несоответствие тренировочных нагрузок, предельная мобилизация функциональных резервов организма, нацеленность на спортивный результат уже на начальных этапах подготовки особенно опасны для юных спортсменов в период, когда окончательная оссификация (процесс формирования костной ткани) еще не состоялась и остается риск неправильного формирования опорно-двигательного аппарата юных спортсменов [15, 29].

Для современного баскетбола характерно выполнение сложных технических приемов и активных тактических взаимодействий в условиях силового прессинга $[5,20]$. В результате баскетбол становится травмоопасным видом спорта [12].

Среди юных баскетболистов распространены травмы опорно-двигательного аппарата, нарушения осанки и плоскостопие $[5,14,28]$. Это связано со спецификой баскетбола, которая проявляется сочетанием ударно-механических взаимодействий стопы с опорой в динамике бега, при отталкивании от опоры в разных прыжках и в процессе приземления. Это приводит к увеличению фиизически нагрузок на опорно-двигательный аппарат спортсменов $[4,10,12,13]$. Риск травматизма усугубляется отсутствием в тренировочной практике профилактических мероприятий.

Проблема профилактики нарушений опорнорессорных свойств стопы рассматривалась разными специалистами $[2,4,6,7]$. Накоплен значительный массив знаний о специфике построения учебно-тренировочного процесса юных баскетболистов; развитии и функционировании организма спортсмена; системе отбора спортсменов $[17-9,27,30] ;$ индивидуализации тренировки на основе игровой специализации баскетболиста и других командных видов спорта [24-26]; об арсенале технико-тактических действий [1]. В отдельных исследованиях отмечено включение в содержание учебно-тренировочного процесса юных баскетболистов на начальном этапе многолетней подготовки физических упражнений и подвижных игр, направленных на укрепление сводов стопы $[1,11]$. Несмотря на ряд научных исследований, вопрос о целенаправленной профрилактике нарушений опорно-рессорных свойств их стопы изучен недостаточно. В частности, мало изучены особенности перемещений в баскетболе и их влияние на состояние стопы у начинающих баскетболистов [13, 20], а известные методы решения данной проблемы не в полной мере учитывают специфику выполнения двигательных действий и требуют совершенствования.

Цель исследования - разработать технологию профрилактики нефиксированных нарушений стопы баскетболистов на начальном этапе многолетней подготовки и определить ее эффективность.

Методы исследования: анализ и обобщение научно-методической литературы, данных сети Интернет, документальных материалов; антропометрия с использованием стопометра (измерение длины и ширины стопы, высоты медиальной части продольного свода стопы, высоты подъема стопы); биомеханический видеокомпьютерный анализ опорно-рессорных свойств стопы с использованием программы «BigFoot» (определение величины угла, образованного плоскостью пола с прямой, проходящей через точку «naviculare», и проекцией на полточки «metatarsale tibiale», характеризующий развитие свода стопы); тензодинамометрия с применением тензоплатформы «Kistler» (оценка биомеханических параметров технических действий в баскетболе при взаимодействии стопы с поверхностью опоры при выполнении юными спортсменами прыжков и оста- 
новок); видеокомпьютерный анализ движений системы «Qualisys» (изучение биомеханических показателей выполнения прыжков и остановок); методы математической статистики [21, 22].

Индекс свода стопы как отношение высоты свода к длине стопы рассчитывали по методу Н. А. Фридленда по фрормуле:

$$
\mathrm{l}=\frac{\mathrm{h}_{\Pi}}{l} 100 \%
$$

где I - искомый индекс (\%), $\mathrm{h}_{\text {п }}$ - высота подъема стопы (см), $l$ - длина стопы (см).

Индекс съода cmonы: 33 \% и выше - очень высокий свод, 33-31 \% - умеренно высокий, 31-29\% - нормальный, 29-27 \% - умеренное плоскостопие, 27-25\% - резкое плоскостопие.

В исследованиях принимали участие 42 юных баскетболиста 8-9 лет, для проведения экспертной оценки - 12 экспертов.

Результаты исследования. Для оценки нагрузки на стопу юных баскетболистов нами было проведено педагогическое тестирование с использованием информативных тестов, определенных 8 экспертами, и данных специальной литературы.

Педагогический эксперимент был проведен в форме констатирующего и фрормирующего. Цель констатирующего эксперимента - определение специфики двигательной функции стопы юных баскетболистов, особенностей взаимодействий между стопой и опорой при выполнении двигательных действий в баскетболе, а также оценка влияния нарушения опорно-рессорных свойств стопы на выполнении двигательных действий. На данном этапе эксперимента участие приняли 29 юных баскетболистов, у 12 из них выявлены нарушения опорно-рессорных свойств стопы, у 17 - нормальная стопа. Установлено, что у юных баскетболистов с нормальной стопой статистически значимо (р < 0,01) бо́льшая длина стопы, высота свода и голеностопного сустава, подъема стоп, больше плюсневой угол альфа $(\alpha)$ и пяточный угол бета ( $\beta)$, а также больший коэффрициент Козырева и индекс Фридланда по сравнению со спортсменами с нарушениями опорно-рессорной фрункции стопы.

На основании результатов экспертизы, проведенной 8 ведущими тренерами по баскетболу и 4 баскетболистами высокой квалификации, оценено влияние нагрузки на стопу при выполнении различных групп технических приемов. Установлено, что наибольшая нагрузка на стопу происходит при прыжках и приемах, которые выполняются в прыжке, а также во время остановок (W $=0,7$ при $p<0,05)$. При этом экспер- тами выделено по два основных вида прыжков и остановок во время игры в баскетбол: прыжок вверх с места отталкиванием двумя ногами и скачок вверх-вперед отталкиванием одной ногой с разбега, а также остановка шагом и остановка прыжком.

Кроме того, экспертами определена значимость (W = 0,93; $\mathrm{p}<0,05)$ средств профрилактики плоскостопия у юных баскетболистов: физические упражнения на упругой поверхности, упражнения на неустойчивой опоре, упражнения на мягкой поверхности и подвижные игры.

Выявлено, что нагрузка на стопу составляет от 986 Н при выполнении прыжка вперед-вверх с разбега толчком одной ногой, до 2518 Н при выполнении остановки прыжком. Минимальные среднестатистические показатели результирующей максимальной силы реакции опоры, зарегистрированные во время выполнения прыжка вперед-вверх с разбега толчком одной ногой, составили 933,29 Н, а максимальные - 2518,64 H, зафиксированы у юных спортсменов во время выполнения остановки прыжком. Установлена значительная горизонтальная составляющая силы реакции опоры, которая в отдельных случаях достигает 1833 Н. Среднестатистическое максимальное значение горизонтальной максимальной силы реакции опоры, которое было зарегистрировано при выполнении спортсменами остановки шагом, составило 1578,53 Н. В то же время максимальное значение вертикальной максимальной силы реакции опоры 749,76 Н у испытуемых наблюдалось при выполнении остановки шагом.

В таблице 1 представлены показатели теста «Прыжок вверх с места отталкиванием двумя ногами» в зависимости от состояния опорно-рессорной ффункции стопы.

Результаты исследований свидетельствуют, что показатели, характеризующие величину нагрузки, превышают вес спортсмена в 2,8 и в 6,0 раз. Кроме того, значение градиента силы свидетельствует о выраженном скоростно-силовом характере нагрузки.

Следует отметить, что нагрузка относительно равномерно распределяется на обе ноги и направлена в большей мере вертикально, поэтому частично амортизируется сводами обеих стоп. Согласно результатам исследования, максимальная сила реакции опоры при отталкивании у юных спортсменов с нормальной стопой превышала вес спортсменов в 3,6 раза, а максимальная сила реакции опоры во время приземления - в 7,5 раз.

Установлено, что высота прыжка у этой группы испытуемых была выше по сравнению с высо- 
ТАБЛИЦА 1 - Показатели теста «Прыжок вверх с места отталкиванием двумя ногами» у юных баскетболистов в зависимости от нарушения двигательной функции стопы ( $n=29)$

\begin{tabular}{|c|c|c|c|c|}
\hline \multirow{3}{*}{ Показатель } & \multicolumn{4}{|c|}{$\begin{array}{l}\text { Наличие нарушений опорно-рессорных } \\
\text { свойств стопы }\end{array}$} \\
\hline & \multicolumn{2}{|c|}{$\begin{array}{l}\text { не установлены } \\
(\mathrm{n}=17)\end{array}$} & \multicolumn{2}{|c|}{$\begin{array}{l}\text { установлены } \\
\quad(n=12)\end{array}$} \\
\hline & $\bar{x}$ & $S$ & $\bar{x}$ & $S$ \\
\hline Вес спортсмена, Н & 269,98 & 31,90 & 272,12 & 18,07 \\
\hline $\begin{array}{l}\text { Максимальная сила } \\
\text { реакции опоры при } \\
\text { отталкивании, Н }\end{array}$ & $971,25^{\star *}$ & 34,59 & 896,81 & 42,30 \\
\hline Градиент силы, H·c ${ }^{-1}$ & $2624,32^{*}$ & 495,97 & 2491,13 & 420,81 \\
\hline Импульс силы, Н·с & $359,27^{*}$ & 31,13 & 322,85 & 56,18 \\
\hline $\begin{array}{l}\text { Максимальная сила } \\
\text { реакции опоры при } \\
\text { приземлении, Н }\end{array}$ & $2026,92^{*}$ & 129,25 & 2106,67 & 161,12 \\
\hline $\begin{array}{l}\text { Продолжительность } \\
\text { фазы амортизации, с }\end{array}$ & 0,19 & 0,02 & 0,20 & 0,02 \\
\hline $\begin{array}{l}\text { Продолжительность } \\
\text { фазы отталкивания, с }\end{array}$ & 0,37 & 0,04 & 0,36 & 0,04 \\
\hline Высота прыжка (м) & $0,31^{*}$ & 0,02 & 0,27 & 0,04 \\
\hline
\end{tabular}

* $\mathrm{p}<0,05$ (** $\mathrm{p}<0,01)$ статистически значимые различия при сравнении показателей юных баскетболистов с нормальной стопой с показателями начинающих баскетболистов с нарушениями опорно-рессорной функции стопы.

той прыжка юных баскетболистов с нарушениями опорно-рессорных функций стопы.

Доказано, что в зависимости от высоты сводов среднестатистические показатели стопы юных баскетболистов имеют статистически значимые различия практически по всем исследуемым параметрам ( $p<0,05)$. Выявлено, что состояние опорно-рессорной функции стопы имеет значительное влияние как на результативность выполнения прыжков, так и на эффрективность выполнения остановок ( $p<0,05)$, что указывает на важность мер для недопущения плоскостопия у юных баскетболистов.

Между силовыми характеристиками в специальных тестах и длиной стопы испытуемых $(p<0,05)$ наблюдается прямая взаимосвязь, которая, в свою очередь, зависит от тотальных размеров тела юных баскетболистов. Увеличение масо-ростовых показателей спортсменов в будущем может привести к повышению нагрузки на опорно-двигательный аппарат стопы. Такие результаты указывают на необходимость включения в тренировочный процесс средств профилактики функций стопы.

Установлено, что показатели опорно-рессорной функции стопы у юных баскетболистов находятся на уровне от низкого до среднего по сравнению с нормами для детей, не занимающихся спортом. Вместе с тем наблюдаются высокие
Спортивна медицина і фізична реабілітація, № 1, 2020

значения коэффрициента корреляции между морфологическими показателями, характеризующими опорно-рессорные фрункции стопы, и биомеханическими характеристиками выполняемых двигательных тестов ( $p<0,05)$.

При выполнении прыжка вверх установлены статистически значимые взаимосвязи:

- на максимальную силу реакции опоры при отталкивании влияет длина стопы ( $r=0,48$; $\mathrm{p}<0,05)$ и высота подъема стопы ( $r=0,39$; $\mathrm{p}<0,05)$;

- между импульсом силы и высотой сводов $(r=0,42 ; p<0,05)$, а также углом $\alpha(\rho=0,41$; $\mathrm{p}<0,05)$

- продолжительность фразы активного отталкивания статистически значимо зависит от высоты сводов стопы $(r=0,32 ; p<0,05)$, а также от величины угла $\alpha$ ( $r=0,33 ; p<0,05)$.

При выполнении теста «Прыжок вперед-вверх с разбега толчком одной ногой» определены взаимосвязи между показателями:

- длина траектории перемещения ОЦМ длина стопы $(r=0,54 ; p<0,05)$; высота сводов $(r=0,45 ; p<0,05)$, высота подъема стопы $(r=0,45 ; p<0,05)$, угол $\alpha(\rho=0,34 ; p<0,05)$;

- горизонтальная максимальная сила реакции опоры - длина стопы $(r=0,41 ; p<0,05)$;

- вертикальная составляющая максимальной силы реакции опоры - высота сводов ( $r=0,33$; $\mathrm{p}<0,05)$.

При выполнении теста «Остановка прыжком» определены статистически значимые взаимосвязи между показателями:

- горизонтальная максимальная сила реакции опоры - длина опорной части стопы $(r=-0,38$; $\mathrm{p}<0,05)$

- горизонтальная максимальная сила реакции опоры - угол $\beta(\rho=0,49 ; p<0,05)$;

- горизонтальная максимальная сила реакции опоры - угол $\gamma(r=-0,50 ; p<0,05) ;$ импульс этой силы - угол $\gamma(\rho=-0,40 ; p<0,05)$;

- горизонтальная составляющая градиента силы - угол $\beta$ ( $\rho=0,33 ; p<0,05)$;

- горизонтальная составляющая импульса силы - угол $\beta(\rho=0,35 ;$ p $<0,05)$; горизонтальная составляющая импульса силы - угол $\gamma(r=$ $=-0,4 ; p<0,05)$.

Таким образом, можно утверждать, что на результативность выполнения прыжка впередвверх с разбега толчком одной ногой влияют длина стопы, высота сводов и высота подъема, а на результативность выполнения остановки прыжком - длина опорной части стопы и углы, характеризующие состояние опорно-рессорной фрункции стопь. 
Нами установлено, что показатели длины стопы и высоты сводов имеют наиболее существенное влияние на максимальную силу реакции опоры (результирующую, вертикальную и горизонтальную составляющие) при выполнении всех тестовых упражнений, а высота подъема стопы в наибольшей степени влияет на длину траектории перемещения ОЦМ.

Можно утверждать, что показатели опорнорессорной функции стопы юных баскетболистов влияют не только на показатели силы реакции опоры, но и на результирующие показатели тестов (высота прыжка, длина траектории перемещения ОЦМ, ускорение ОЦМ спортсмена), что доказывает необходимость проведения мероприятий, направленных на укрепление сводов стопы и проорилактику плоскостопия юных баскетболистов. Таким образом, улучшение показателей свода стопы должно положительно сказаться на спортивных результатах спортсменов.

Полученные данные, а также результаты экспертного опроса, стали основанием для разработки авторской технологии профилактики опорно-рессорных характеристик стопы юных баскетболистов, цель которой совершенствова- ние учебно-тренировочного процесса на начальном этапе многолетней подготовки (рис. 1).

Внедрение предложенной технологии предусматривало учет принципов спортивной тренировки, среди которых целесообразность, управляемость, положительная мотивация, систематичность, вариативность, единство общей и специальной подготовки, взаимообусловленность эфрфективности тренировочного процесса и профрилактики спортивного травматизма, единство и взаимосвязь тренировочного процесса и соревновательной деятельности и т.д. а также принципов обучения, таких, как сознательность и активность, наглядность, систематичность и постепенность и т.д.).

Как основное средство профрилактики плоскостопия у юных баскетболистов предусматривалось применение фризических упражнений на упругой и мягкой поверхностях, неустойчивой опоре, а также подвижных игр.

Комплексы фризических упражнений были интегрированы в содержание учебно-тренировочного процесса и проводились в подготовительной части занятия во время разминки. Подвижные игры тесно связаны с другими средствами обу-

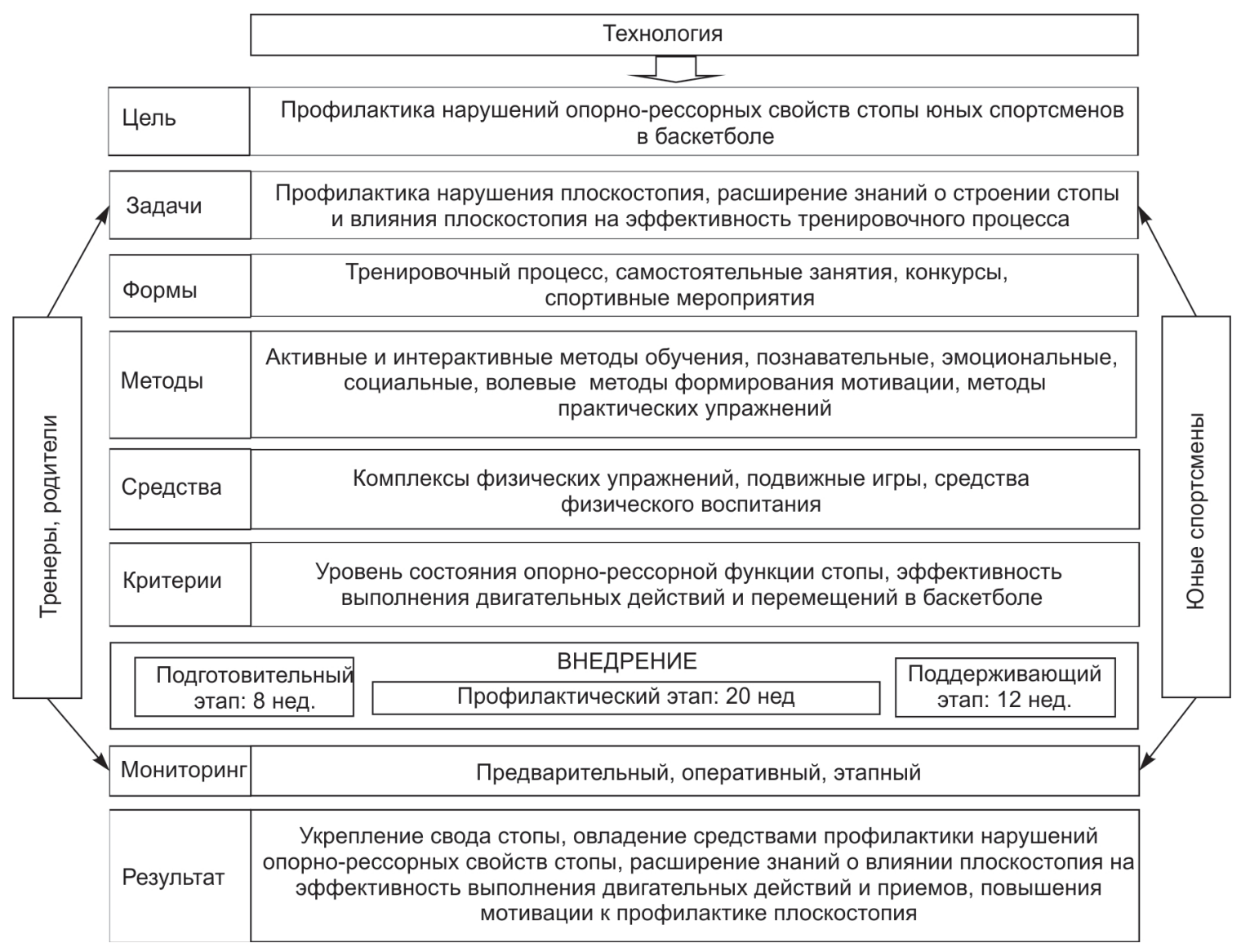

Рисунок 1 - Технология профилактики нарушений опорно-рессорных свойств стопы юных баскетболистов 
чения и тренировки в соответствии с возрастом, уровнем фризической подготовленности и спецификой двигательной деятельности спортсменов в баскетболе.

Подготовительный этап (8 нед.) предусматривал ознакомление с помощью методических карт «Источник здоровья стопы» с теоретическими данными, использование подвижных игр и командных эстафет. Во второй половине основной части занятия использовались комплексы фризических упражнений, связанные с перемещением и захватом предметов, которые включали упражнения на ползание, лазание, перелазание, а в заключительной части - упражнения на развитие гибкости и подвижности в суставах стопы, среди которых преобладали упражнения в положении сидя, лежа, элементы самомассажа стоп на массажных ковриках, ребристых досках. На данном этапе были предложены комплексы фризических упражнений для самостоятельного выполнения под присмотром родителей. Мотивационный блок направлен на стимулирование интереса юных спортсменов к систематическим занятиям баскетболом, создание благоприятного психологического климата в коллективе, формирование навыков взаимодействия в группе.

Проффилактический этап (20 нед.) включал теоретические сведения о строении стопы, о видах нарушения ее опорно-рессорных свойств, профилактике уплощения стопы у спортсменовбаскетболистов, фрормировал интерес к систематическим занятиям баскетболом. Карты «Источник здоровья стопы» включали методические указания мониторинга состояния стопы и комплексы фризических упражнений для самостоятельного выполнения под контролем родителей.

В практический блок вошли комплексы специальных фризических упражнений на неустойчивой, мягкой и упругой опорах. Комплексы физических упражнений на неустойчивой опоре предусматривали использование балансирующей платформы «Bosu» и балансирующей подушки. Изменения в комплексы фризических упражнений вносились в соответствии с периодом тренировок.

Для поддержиВающего этапа (12 нед.) характерным было уменьшение фризической нагрузки в сравнении с профрилактическим этапом, расширение теоретических знаний и поддержка положительной мотивации. Направленность физических упражнений (на растягивание, элементы самомассажа) способствовала восстановлению и созданию благоприятного психологического климата в спортивной команде. Широко использовались подвижные игры.
Оценка эффрективности внедрения технологии профилактики нарушений опорно-рессорных свойств стопы юных спортсменов осуществлялась на этапе формирующего эксперимента, в котором приняло участие 25 баскетболистов с нарушениями опорно-рессорной функции стопы (контрольная группа (КГ) - 12 человек, основная группа (ОГ) - 13 человек). Спортсмены ОГ занимались по разработанной нами технологии, а представители КГ - по общепринятой программе ДЮСШ. После 40 нед. регулярных занятий проведены повторное исследование и анализ влияния предложенной технологии на состояние опорно-рессорных характеристик стопы при выполнении двигательных действий в баскетболе.

У спортсменов ОГ наблюдался положительный прирост показателей состояния опорно-рессорных свойств стопы. У спортсменов КГ высота свода увеличилась на 4 \%, у спортсменов ОГ на $33,3 \%$. В то же время индекс Козырева у баскетболистов КГ не изменился, в ОГ увеличился на 35,3 \%. В ОГ наблюдалось статистически значимое увеличение индекса Фридланда $(p<0,05)$ и его среднее значение приблизилось к норме, что свидетельствовало о положительной динамике улучшения опорно-рессорных свойств сводов стопы у юных баскетболистов (табл. 2). У спортсменов КГ эфрфективность выполнения прыжка вверх с места отталкиванием двумя ногами увеличилась на 8,8 \%, в ОГ - на $24,2 \%$. Улучшились показатели выполнения прыжка вверх-вперед с разбега отталкиванием одной ногой: в КГ высота прыжка увеличилась на $5,6 \%$, в ОГ - на $16,7 \%$. В ОГ также статистически значимо увеличилось ускорение ОЦМ при выполнении остановок прыжком и при остановке шагом $(p<0,05)$.

Таким образом, можно констатировать, что технология профилактики нарушений опорнорессорных свойств стопы создает предпосылки для повышения результативности игрока. Ее можно рекомендовать как для укрепления сводов стопы, так и для повышения эфрфективности выполнения основных технических приемов юных баскетболистов.

Дискуссия. Состояние здоровья детей, занимающихся спортом, является лимитирующим фрактором будущих успехов и результативности. Высокий уровень фризического здоровья позволяет спортсмену выдержать большие нагрузки, раскрыть свой потенциал и добиться признания в выбранном виде спорта. Особое место в системе подготовки спортсменов занимает профилактика травматизма уже с начального этапа подготовки баскетболистов. 
ТАБЛИЦА 2 - Динамика антропометрических показателей стопы юных баскетболистов после внедрения технологии профилактики нарушений опорно-рессорных свойств стопы $(\mathrm{n}=25)$

\begin{tabular}{|c|c|c|c|c|c|c|c|c|}
\hline \multirow{3}{*}{ Показатель } & \multicolumn{4}{|c|}{ Контрольная группа ( $n=12)$} & \multicolumn{4}{|c|}{ Основная группа $(n=13)$} \\
\hline & \multicolumn{2}{|c|}{ До } & \multicolumn{2}{|c|}{ После } & \multicolumn{2}{|c|}{ До } & \multicolumn{2}{|c|}{ После } \\
\hline & $\bar{x}$ & $\mathbf{s}$ & $\bar{x}$ & $\mathbf{s}$ & $\bar{x}$ & $\mathbf{s}$ & $\bar{x}$ & s \\
\hline Длина стопы, мм & 188,96 & 13,98 & $189,19^{*}$ & 13,91 & 192,81 & 13,81 & $190,63^{*}$ & 18,77 \\
\hline Длина опорной части стопы, мм & 129,84 & 10,00 & $138,62^{*}$ & 11,81 & 136,08 & 10,97 & $131,02^{*}$ & 16,75 \\
\hline Высота сводов стопы, мм & 22,94 & 3,38 & 26,72 & 3,73 & 25,68 & 3,90 & $28,76^{*}$ & 4,28 \\
\hline Высота голеностопного сустава, мм & 60,39 & 5,84 & 63,56 & 4,75 & 62,71 & 4,65 & 62,32 & 6,54 \\
\hline Высота подъема стопы, мм & 37,92 & 4,36 & 38,08 & $3,80^{*}$ & 38,96 & 3,60 & $40,94^{*}$ & 4,16 \\
\hline Угол а, град. & 17,43 & 3,43 & 18,98 & 2,51 & 17,85 & 1,65 & $21,02^{*}$ & 3,15 \\
\hline Угол $\beta$, град. & 22,61 & 3,89 & 24,09 & 4,72 & 24,79 & 5,21 & $27,75^{*}$ & 5,27 \\
\hline Угол $\gamma$, град. & 139,97 & 6,28 & 136,92 & 6,69 & 137,36 & 6,43 & $131,23^{*}$ & 7,27 \\
\hline Коэффициент Козырева & 0,18 & 0,03 & $0,19^{*}$ & 0,03 & 0,19 & 0,03 & $0,22^{*}$ & 0,04 \\
\hline Индекс Фридланда, \% & 27,80 & 7,29 & 27,88 & 2,13 & 27,88 & 2,13 & $31,11^{* *}$ & 4,11 \\
\hline
\end{tabular}

* $p<0,05$ (** $p<0,01)$ статистически значимые различия при сравнении показателей юных баскетболистов до и после исследования.

Лидерами по количеству травм являются игровые виды спорта [16], что подтверждено исследованиями Э. Дорошенко [3] (рис. 2).

Одним из нарушений ОДА, которые могут влиять на уход из спорта юного спортсмена, является нарушение опорно-рессорной функции стопы. А. В. Гуров вводит понятие «спортивная стопа», указывая, что ее особенностями являются многочисленные деформации и заболевания [2].

Согласно результатам исследований А. И. Перепелкина, процент с отсутствием нарушений в состоянии стопы среди юношей, не занимающихся спортом, даже больше, чем у юных спортсменов (табл. 3) [7, 8].

Среди юных спортсменов процент с серьезными отклонениями состояния стопы в 2,2 раза больше по сравнению с нетренированными юношами, а режим чрезмерной двигательной активности, связанный с нагрузкой на стопу, негативным образом отражается на ее состоянии $[7,8]$.

В ходе исследований и последующего обобщения данных было установлено, что среднеста- тистические показатели морфобиомеханичних характеристик стопы напрямую зависят от спортивной специализации обследуемых и обусловлены характером спортивной деятельности, особенностями тренировочного режима, периодом подготовки, квалификацией, возрастом начала специализации в данном виде спорта и спортивным стажем. Существует нормативная шкала оценки плантографрических показателей стопы отдельных групп спортсменов и лиц, не занимающихся спортом, свидетельствующая о заметной вариативности указанных показателей в зависимости от вида спорта [4].

Изменение морфофрункциональных особенностей стопы происходит под действием внешних для нее сил, таких, как масса звеньев тела, расположенных над стопой, что составляет почти 94 \% общей массы тела человека; реакции опоры, возникающей при контакте звеньев с опорой [10]. По данным исследований Л. Н. Рютиной [9], доля отклонений от нормального состояния стопы в среднем наблюдается в 63,7 \% случаев, причем в 38,9 \% случаев отмечено нарушение на обеих стопах.

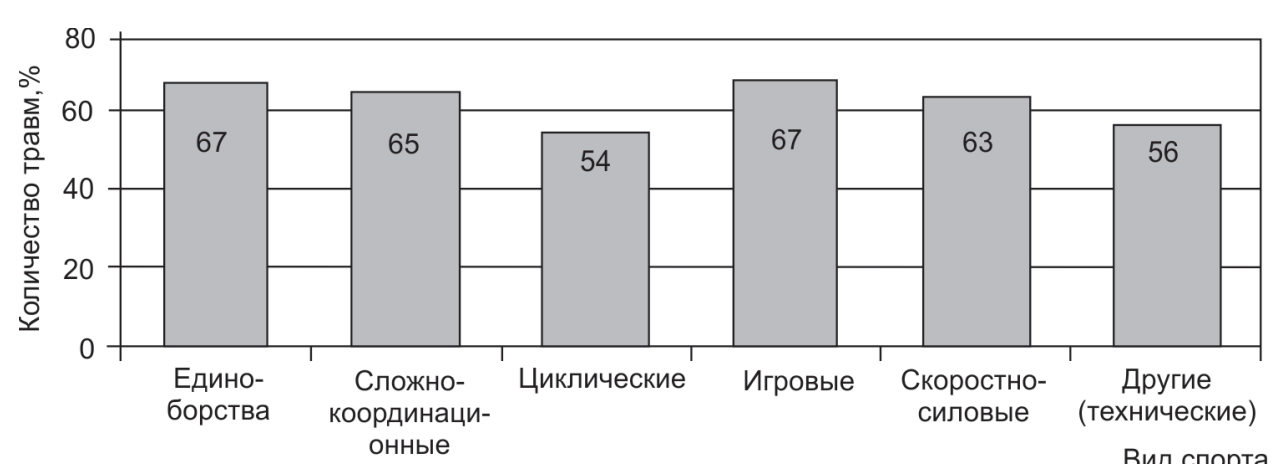

Рисунок 2 - Травмы опорно-двигательного аппарата в разных видах спорта [3] 
У подавляющего большинства юных баскетболистов, у которых определено нарушение состояния стоп, наблюдается статическое плоскостопие, которое провоцируют слабость мышц голени и стопы, поддерживающих своды [10, 11], а также избыточная масса тела, неудобная обувь и чрезмерные фризические нагрузки.

Нагрузки на стопу баскетболистов в процессе многолетней подготовки имеют тенденцию к росту. Стопа как биологически важный орган опоры обеспечивает естественные локомоции и осуществление опорных взаимодействий спортсменов, а нарушения ее функций негативным образом влияет на физическое состояние юного спортсмена, его результативность и спортивное долголетие. Двигательная деятельность спортсменов-баскетболистов состоит из разных видов бега, прыжков и бросков мяча и связана с особым взаимодействием между стопой и опорой.

Определено, что наиболее значительными являются нагрузки на стопу при выполнении прыжков вверх и вверх-вперед, серии прыжков толчком одной или двумя ногами, а также остановок, что обусловлено увеличением массы и длины тела спортсменов, скоростно-силовых способностей игроков, объемов и интенсивности тренировочной нагрузки. Существует необходимость внедрения на этапе начальной подготовки фризических упражнений, направленных на укрепление мышц стопы и профилактику плоскостопия.

В тренировочный процесс юных баскетболистов следует ввести профрилактически-реабилитационное направление, которое сочетает педагогические, медико-биологические, содержательно-профессиональные, организационные аспекты [5].

Однако в ходе исследования установлено, что наиболее перспективным направлением совершенствования тренировочного процесса юных спортсменов являются технологии профилактики нарушений опорно-рессорной фрункции стопы, которые были разработаны нами на основе установленных особенностей взаимодействий между стопой и опорой при игре в баскетбол.

\section{Выводы}

Выявлено негативное влияние нарушений стопы на опорную реакцию юных баскетболистов при выполнении основных технических приемов: при выполнении прыжка вверх с места отталкиванием двумя ногами. Максимальная сила реакции опоры при отталкивании колеблется в
Спортивна медицина і фізична реабілітація, № 1, 2020

ТАБЛИЦЯ 3 - Структура деформации стопы у юношей, не занимающихся спортом, и юных спортсменов [nо: 7,8$]$

\begin{tabular}{|c|c|c|}
\hline $\begin{array}{c}\text { Степень } \\
\text { деформации }\end{array}$ & $\begin{array}{c}\text { Юноши, не } \\
\text { занимающиеся спортом }\end{array}$ & $\begin{array}{c}\text { Юные } \\
\text { спортсмены }\end{array}$ \\
\hline Отсутствие нарушений & 5,9 & 3,5 \\
\hline I & 70,5 & 53,8 \\
\hline II & 21,0 & 37,1 \\
\hline III & 2,6 & 5,6 \\
\hline
\end{tabular}

пределах от 1243 до 1476 Н, при приземлении от 2437 до $2976 \mathrm{H}$; зарегистрированнная высота прыжка составила от 0,28 до $0,41 \mathrm{~m}$.

У начинающих спортсменов с нарушениями опорно-рессорных свойств стопы указанные среднестатистические показатели составили 1315,42 и 2806,67 Н соответственно при среднегрупповой высоте прыжка 0,34 м.

У юных баскетболистов с нормальной стопой статистически значимо выше показатели высоты прыжка вверх-вперед с разбега отталкиванием одной ногой $(p<0,05)$, длины прыжка $(p<0,05)$, длины траектории перемещения ОЦМ за прыжок $(p<0,05)$ в сравнении со спортсменами, имеющими нарушения опорно-рессорной функции стопы. Нарушение состояния стопы негативно сказывается на выполнении спортсменами остановок прыжком и шагом.

Разработанная технология профилактики нарушений опорно-рессорных свойств стопы юных баскетболистов позволила, не нарушая тренировочного процесса, ввести комплекс фризических упражнений (на неустойчивой опоре, предусматривающий использование балансирующей платформы «bosu»; на упругой и мягкой поверхностях), подвижные игры, способствующие укреплению мышечно-связочного аппарата стопы; расширить знания о влиянии плоскостопия на эфффективность игры, усилить мотивацию к регулярному выполнению профилактических упражнений.

Предложенная технология профилактики нарушений опорно-рессорных свойств стопы юных баскетболистов положительно повлияла на восстановление состояния стопы и способствовала укреплению ее сводов у юных спортсменов.

Перспектива дальнейших исследований заключается в поиске новых подходов к организации мероприятий, направленных на профилактику нарушений опорно-рессорной функции стопы баскетболистов на других этапах многолетней подготовки. 


\section{Литература}

1. Величенко МА, Фотинюк ВГ, Коротя ВВ, Тимошкін ВМ. Фізичне виховання [Physical education]. Практикум. Баскетбол. Київ: Національний авіаційний університет; 2014. 69 с.

2. Гуров АВ. Восстановление функции стопы при различных видах плоскостопия с помощью индивидуально конструируемых ортезов [Foot function recovery during different types of flatfoot by means of individually designed orthoses] [диссертация]. Москва; 2009. 189 с.

3. Дорошенко Е. Стан опорно-рухового апарату юних спортсменів як паритет розробки здоров'ясрормувального напряму в процесі багаторічної підготовки. Молодіжний науковий вісник Східноєвропейського національного університету ім. Лесі Українки. 2017;26:103-7.

4. Лапутин А, Кашуба В, Гамалий В, Сергиенко К. Диагностика морфоффункциональных свойств стопы спортсменов [Diagnosis of athlete foot morphofunctional properties]. Наука в Олимпийском сnорте. 2003;1:6774.

5. Орловская ЮВ. Теоретико-методологическое обоснование профилактическо-реабилитационного направления в системе подготовки спортивных резервов: на примере специализации баскетбол [Theoreticomethodological substantiation of preventive and rehabilitative direction in the system of sports reserve preparation: on example of basketball] [авторефрерат]. Москва; 2000. 49 c.

6. Перепелкин АИ, Ефремова ГВ, Букина ЕВ. Сравнительный анализ морфоффункционального состояния стоп у спортсменов различных специализаций [Comparative analysis of foot morphofunctional state in athletes of different specializations]. Вестник Волгоград. гос. мед. ун-та. 2007;1(21):7-9.

7. Перепелкин АИ, Царапкин ЛВ. Морфоорункциональные параметры стопы человека [Morphofunctional parameters of human foot]. Травматология и ортопедия. 2008;4(50):100-101.

8. Платонов ВН. Система подготовки спортсменов в олимпийском спорте. Общая теория и её практические приложения [System of athletes' preparation in the Olympic sport. General theory and its practical applications]. Киев: Олимпийская литература; 2015. 770 c.

9. Рютина ЛН. Методика профилактики нарушений и укрепления свода стоп у детей школьного возраста [Methods of preventing disorders and strengthening foot arch in school children] [диссертация]. Омск; 1997. $198 \mathrm{c}$.

10. Сергиенко КН, Строганов СВ. Биомеханические особенности опорных взаимодействий юных баскетболистов в зависимости от высоты продольного свода стопы [Biomechanical peculiarities of support interactions of young basketball players depending on height of longitudinal foot arch]. B: Актуальные проблемы экологии и здоровья человека. Материалы I Междунар. науч.-практ. конф.; 2013 Апр 25; Череповец. Череповец; 2013. C. 140-3.

11. Сергиенко КН, Строганов СВ. Профилактика нарушений опорно-рессорных свойств стопы баскетболистов на начальном этапе многолетней тренировки. Probleme actuale privind perfectionarea sistemului de invatamint in domeniul culturii fizice. Materialele conferintei stintifice intermationale; 2013. N 8-9; Chisinau. Chisinau: USEFS, (Молдова); 2013. C. 461-4.

12. Степанов КС, Коняхина ГП. Травматизм в баскетболе и его профилактика [Traumatism in basketball and its prevention]. Учебное пособие. Челябинск; 2016. 64 с

13. Строганов С, Сергієнко К. Сучасні підходи до аналізу особливостей взаємодії між стопою і опорою під час гри в баскетбол []. Теорія і методика фізичного виховання і спорту. 2013;2:122-7.

14. Строганов С, Шинкарук О, Сергієнко К, Бишевець Н, Гончарова Н, Жирнов О. Профілактика порушень опорно-ресорних властивостей стопи юних баскетболістів // Матеріали II Всеукраїнської електронної конференції 3 міжнародною участю «Інноваційні та інформаційні технології у фізичній культурі, спорті, фізичній терапії та ерготерапії», 18 квітня 2019 року. Київ: НУФВСУ, 2019: 50-2.

15. Сушко Р. До питання профілактики функціональних порушень опорно-рухового апарату юних спортсменів [To the issue of preventing functional disorders of young athlete locomotorium]. Молодіжний науковий вісник
Східноєвропейського національного університету імені Лесі Українки. 2018;29:33-8.

16. Шинкарук О. Актуальные проблемы медицинского и научного обеспечения в олимпийском спорте [Actual issues of medical and scientific support in the Olympic sport]. Спортивна медицина і фізична реабілітація. 2019; 1: 16-27.

17. Шинкарук О. Узагальнення досвіду організації відбору в олімпійському спорті [Generalization of experience of selection organization in the Olympic sport]. Теорія і методика фрізичного виховання і спорту. 2001;2-3: 35-9.

18. Шинкарук ОА. Обірунтування використання фізіологічних показників як критеріїв відбору спортсменів у циклічних видах спорту [Substantiating the use of physiological indices as the criteria of athlete selection in cyclic sports events]. Актуальні проблеми фрізичної культури і спорту: зб. наук. пр. 2004; 3: 52-5.

19. Шинкарук О. Особливості організації відбору спортсменів у циклічних видах спорту [Features of athlete selection organization in cyclic sports events]. Теорія і методика фрізичного виховання і сnорту. 2002; 1 $34-42$.

20. Шинкарук О, Мітова О. Система контролю підготовки початківців у командних спортивних іграх: проблемні питання та сучасні підходи [System of control for novice preparation in team sports games: issues and modern approaches]. Спортивний вісник Придніпров'я: науково-практичний журнал. 2017; 1:105-12.

21. Byshevets $N$, Shynkaruk O, Stepanenko O, Gerasymenko S Tkachenko S, Synihovets I, Filipov V, Serhiyenko K, lakovenko O Development skills implementation of analysis of variance at sport-pedagogical and biomedical researches. Journal of Physical Education and Sport. 2019; 19 (6), Art 31: 2086-90, 2019. DOI:10.7752/jpes.2019.s6311

22. Byshevets N, Denysova L, Shynkaruk O, Serhiyenko K, Usychenko V, Stepanenko O, Syvash I. Using the methods of mathematical statistics in sports and educational research. Journal of Physical Education and Sport. 2019; 19 (3), Art 148: 1030-34, 2019 DOI:10.7752/jpes.2019.s3148

23. Kostiukevych V, Lazarenko N, Shchepotina N, Poseletska K, Stasiuk V, Shynkaruk O, Borysova O, Denysova L, Potop V, Vozniuk T, Dmytrenko S, KulchytskA I, Konnova M, lakovenko O. Programming of the training process of qualified football players in the competitive period of the macrocycle. Journal of Physical Education and Sport. 2019; 19 (6), Art 329: 2192-99, 2019. DOI:10.7752/jpes.2019.s6329

24. Kostiukevych V, Imas Y, Borisova O, Dutchak M, Shynkaruk O, Kogut I, Voronova V, Shlonska O, Stasiuk I. Modeling of training process of athletes in sports games in annual macrocycle. Journal of Physical Education and Sport. 2018; 18 (1), Art 44: 327-34. 2018.

25. Kostiukevych V, Shchepotina N, Zhovnych O, Shynkaruk O, Koliadych Yu, Hatsoieva L, Voronova V, Vozniuk T, Kaplinskyi V, Diachenko A, Chernyshenko T, Konnova M. Highly Qualified Grass Hockey Sportswomen's Adaptation to Training Intensity in the Macrocycle Preparatory Period. Journal of Physical Education and Sport. 2020; 20 (1), Art 55: 385-94, 2020. DOI:10.7752/ jpes.2020.s1055

26. Kostiukevych V, Shynkaruk O, Kulchytska I, Borysova O, Vozniuk T, Yakovliv V, Denysova L, Konnova M, Khurtenko O, Perepelytsia O, Polishchuk $V$, Shevchyk $L$. Training process construction of the qualified volleyball women players in the preparatory period of two-cycle system of the annual training on the basis of model training tasks. Journal of Physical Education and Sport. 2019; 19 (2), Art 63: 427-35, 2019

27. Shynkaruk 0 . Hereditary and acquired characteristics in the process of sporting selection (Спадкові та набуті ознаки в процесі спортивного відбору). Спортивна наука та здоров'я людини. 2019; 1 (1): 64-73.

28. Stroganov S, Sergiyenko K. Prevention and Correction of the Foot Supporting-Spring Qualities Disorder of Young Basketball Players. Молодіжний науковий вісник Волинського національного університету імені Лесі Українки. 2012; 7:95-7.

29. Stroganov S, Serhiyenko K, Shynkaruk O, Byshevets N, Denysova L, Yukhno Yu, Stepanenko O, Ulan A. Features of preventive activity at the initial stage of training of many years standing of young basketball players. 
Journal of Physical Education and Sport. 2020; 20 (1), Art 66: 452-455, 2020; DOI:10.7752/jpes.2020.s1066

30. Tretiak O, Danylo S, Konovalska L, Bazylchuk O, Sushchenko L, Bazylchuk V, Shynkaruk O, Denysova L. Factor structure of interrelation between

shi-oksana@ukr.net indices of physical condition and definition of the level of physical readiness of future specialists in higher pedagogical education to act in extreme situations. Journal of Physical Education and Sport. 2020; 20 (1), Art 68: 46-68, 2020. DOI:10.7752/jpes.2020.s1068

Надійшла 28.01.2020 